166

Received: July 30, 2012

Accepted: December 15, 2012
Macedonian Journal of Animal Science, Vol. 3, No. 2, pp. 167-173 (2013)

In print ISSN $1857-6907$

On line ISSN $1857-7709$

UDC: 636.39 .034

Original scientific paper

\title{
IMPORTANCE OF BODY CONDITION SCORE IN DAIRY GOATS
}

\author{
Mehmet Koyuncu, Şeniz Öziş Altınçekiç \\ Uludag University Faculty of Agriculture, Department of Animal Science, \\ 16059, Görükle, Bursa, Türkiye, \\ koyuncu@uludag.edu.tr
}

\begin{abstract}
Routine scoring of the body condition of dairy animals can help detect potential problems that might cause a decrease in milk production. As the production level of a herd increases, the body condition scoring becomes more important. A routine program for body condition scoring can help detect potential health problems before they significantly reduce milk production. A herd of goat that is in good body condition will not only produce more, but will also be less susceptible to metabolic disorders, diseases, mastitis and reproductive problems.
\end{abstract}

Key words: dairy goat; body condition score

\section{ВАЖНОСТ НА ОЦЕНКАТА НА ТЕЛЕСНАТА КОНДИЦИЈА КАЈ МОЛЗНИ КОЗИ}

Рутинската оценка на состојбата на телото на молзни животни може да помогне во откривање на потенцијалните проблеми кои би можеле да предизвикаат намалување на производството на млеко. Како што се зголемува нивото на производство во стадото, оценката на телесната состојба станува доста важна. Рутинска програма за оценка на телесната состојба може да помогне во откривање на потенцијални здравствени проблеми пред тие значително да го намалат производството на млеко. Стада кози кои се во добра телесна кондиција не само што ќе произведуваат повеќе, туку и ќе бидат помалку подложни на метаболички нарушувања, болести, маститис и репродуктивни проблеми.

Клучни зборови: молзна коза; оценка на телесна кондиција

\section{INTRODUCTION}

Condition is the performance of animals in any given period. BCS is an estimate of the muscle and fat development of an animal. Muscles become toned and larger with exercise, but there is a point where additional muscle size cannot increase much. Fat is needed as an energy reserve to get animals through stressful times, either during health problems or dietary inadequacies. Animals need a certain amount of internal fat to function well. Animals in appropriate (medium) body condition have adequate energy/fat reserves to fulfill their genetic potential without the excess fat which seriously impairs performance (Kinne, 2012). Body condition score (BCS) is thus an estimation of muscle and fat development of an animal and is correlated with the direct measurement of backfat depth or the proportion of fat in the animal body providing a better estimate than body weight alone (Russel et al., 1969; Sanson et al., 1993). BCS is also a subjective way to evaluate the nutritional status of a flock and acts as a potential indicator for goat owners to increase the production efficiency in their flock (Özder et al., 1995; Sejian et al., 2010).

Body fat reserve in dairy goats bears importance in terms of milk production, fertility, feed consumption and general health of the animal. In extremely skinny goats with insufficient body fat reserve, milk yield falls behind since body reserve fails to support milk production at the beginning of lactation. Some non-microbic diseases are met more widely (ketoses, dislocation of abomasums) and rutting is less common. In extremely fat goats on the other hand it becomes more common to witness difficult deliveries and related complications. At the onset of lactation tendency to catch 
some metabolic diseases causing a fall in the consumption of dry material performs a rise (ketosis etc.) whilst a fall is observed in milk yield (Cisse et al., 1992; Luginbuhl, 1998). Knowing body fat level of goats during lactation period makes flock management easier since it allows monitoring energy consumption.

By knowing the body condition it becomes possible immediately to detect changes and sudden losses in condition which are hard to observe from the outer appearance of animal. By monitoring body mass changes thus controlling feeding it becomes possible to use feed resources more effectively (Biçer, 1991).

\section{BCS SYSTEM FOR DAIRY GOAT}

Jefferies (1961) first described a method for condition scoring of sheep, later it was refined by Russel (1984), which was based on manual palpation of the loin region in order to assess the degree of longissimus dorsi muscle (eye muscle or loin), and fat cover over the spinal and transverse processes of the lumbar vertebrae. However, the distribution of the body fat in goats differs appreciably from that in ewes (Colomer et al., 1987). For instance, fat deposits in the dorsal region are not highly noticeable, and when the BCS method has used the dorsal and lumbar regions to predict fat stores in goats, the results have not proven to be very satisfactory. For this reason, the BCS has been determined is using the sternal region, where large amounts of fat accumulate in goats (Hervieu et al.,1991). Goats are given a BCS of 1 (very thin) to 5 (very fat), based on the level of muscling and fat deposition around the loin region. (Anonymous, 2010; Anonymous, 2012; Villaquiran et al., 2012). Body condition score of dairy goats are as demonstrated in Figure1.

BCS is used for evaluating the current and past feeding program, assessing the health status of individual animals, and establishing the condition of animals during routine animal management. BCS provides an indication of the energy status of goats, being largely an index of the amount of muscle and degree of fatness of the animals. When evaluating goats, the amount of fat under the chest (sternal fat) and over the ribs should also be evaluated. This is particularly important in dairy goats. As with lactating cows, having goats in a proper body condition will lead to higher production and healthier does. Goats that are very fat at kidding will result in more health problems. Goats that are very thin in early lactation will not have the energy reserves required to attain high milk production. Thin goats at breeding will also be harder to get pregnant. Healthy, well nourished goats should not be very fat or very thin (Houghton et al., 1990; Pennington, 2010).

It is also important to note that BCS could vary according to the physiological status of the animal. An example which shows such a change is depicted in Figure 2. for does. At the time of mating does should have a score of 3 for optimum result with a range of 2 to 3 being acceptable. Pregnant females need to be watched closely to make sure they are close to a score of 3 throughout this period. After the kids are born and during lactation, it is normal for BCS in does to reduce. Lactation is demanding in terms of nutrient requirements. If lactating animals are not fed properly during this period, body reserves could be mobilized, resulting in poor body condition. Lack of attention during this period will impact the growth of the nursing kid as well as milk yield. Under ideal conditions, does should never be allowed to go below a BCS of 2. The same is true of the higher end of the scale. Does should not reach a BCS of 4 , and should never reach a BCS of 5. Does can increase in body mass, even in early lactation, with adequate, good quality feed. However, in most cases, there is a decrease in the body mass in early lactation when milk production is high and an increase in the body mass in later lactation with declining milk production. In such cases, BCS is useful in adjusting supplementary feeding up or down (Girma and Alemu, 2012).

\section{RELATIONSHIPS BETWEEN BCS AND SOME YIELDS IN GOATS}

Several authors recommend evaluation of BCS because it reflects the nutritional status (Short et al.,1990; Arregu'in et al., 1997; Tarr and Gain, 2008; Zahraddeen et al., 2008). The nutritional status or balance of an animal, evaluated through BCS, reflects the body reserves available for basic metabolism, growth, lactation and activity. Body fat is indicative of the energy stored. To maintain health, reproductive function and productive capacity, females must have adequate amounts of body reserves, particularly dairy goat. When goats have low body energy reserves they may have a greater probability of suffering from diseases, metabolic disorders, reproductive failure and reduction in milk yield. Dairy goats with excessive 
fat reserves or over-condition at kidding may have a greater risk of lower milk yield and of increased health and reproductive disorders, such as dystocia and fatty liver. According to Luginbuhl and Poore (1998), animals with extremely good body condition tend not to respond to flushing.

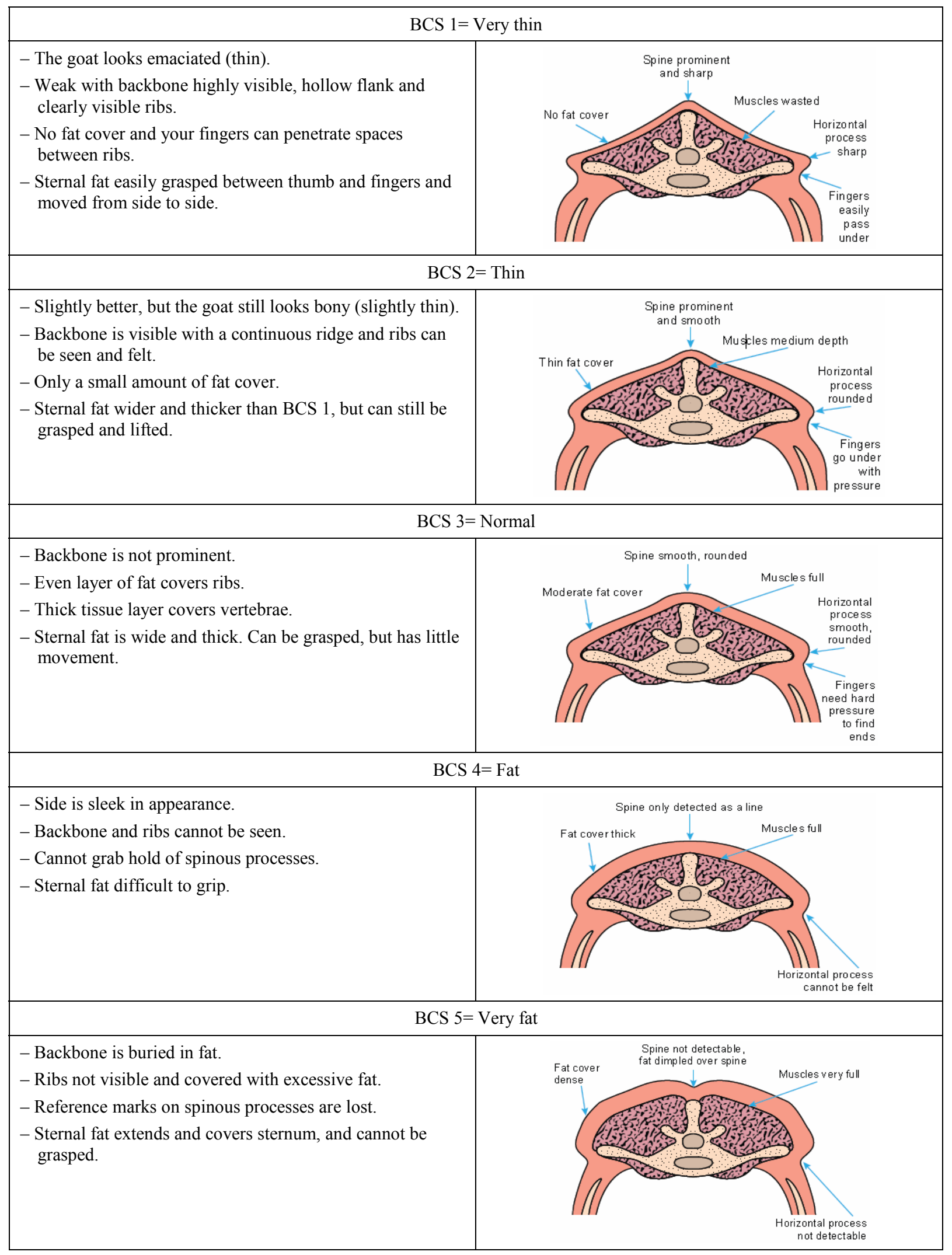

Figure1. Body condition score of dairy goat 


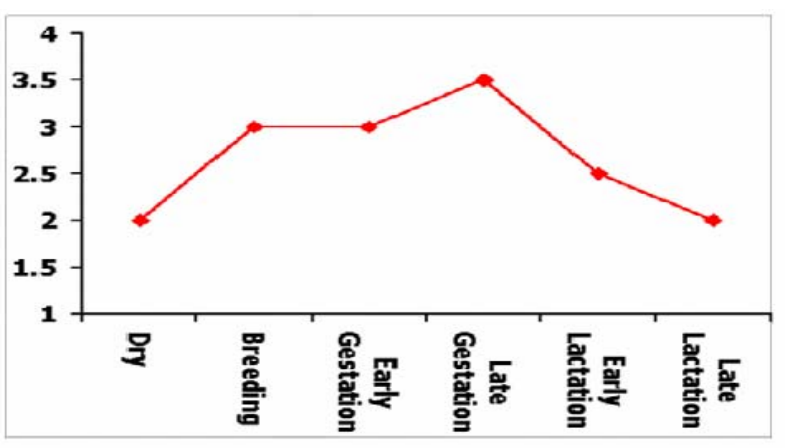

Figure 2. Expected body condition score changes throughout a doe's production cycle

Very fat goats are at greater risk of developing pregnancy toxaemia, especially when they carry twins or triplets. Some authors (Smith and Sherman, 1994; Rook, 2000; Radostits et al., 2007), refer to this particular pregnancy toxaemia as "fat doe pregnancy toxaemia" (estate ketosis) which is caused by over-conditioning of the flock, herd or individual during early pregnancy. According to Pugh (2002), pregnant goats should have a body condition score of between 2.5 and 3 some 45 days before parturition.

Oregui et al. (1991) have reported that one unit of change in BCS equals around 5 kilograms of change in the live weight. Sanson et al. (1993), have argued that there is a high correlation between live weight and BCS and related that one unit of increase in BCS triggered 5.1 kilograms of change in the live weight. Dinler (2005), has detected that one unit of change in condition score created $3.836 \mathrm{~kg}$ of change in the live weight; $3.003 \mathrm{~kg}$ of change in the mid-pregnancy; $2.33 \mathrm{~kg}$ of change during delivery; $2.721 \mathrm{~kg}$ of change in lactation. Cisse et al., (1992) have noted that the the body condition can be optimized in goats with a balanced and sufficient diet and that shifts in the body weight are not necessarily parallel to body condition score at all times.

There is then an optimum BCS for each goat in the flock and for each stage of the production cycle. There are many reports suggesting a positive correlation between BCS at mating and reproductive performance (Russel et al., 1969; Teixeira et al., 1989; Gunn ve Doney, 1975; Atti et al., 2001; Abdel-Mageed, 2009; Sejian et al., 2010; Yilmaz et al., 2011). BCS directly affects hypothalamic activity and GnRH secretion, but not pituitary sensitivity to $\mathrm{GnRH}$, and these effects on reproductive performance are also mediated through changes in ovarian hormones or in hypothalamo-pituitary sensitivity to ovarian hormones (Rhind et al., 1989).
Animals which having a good condition score in mating (3-3.5) offspring yield is compared to other animals much higher (Biçer, 1991). That is why goats should receive BCS 8 weeks prior to mating, the animals should be classified into groups; animals with poor condition should receive flushing to reach sufficient scores (3-3.5) and animals which receive scores higher than 4 should be fed with low-energy food to reach optimum 3-3.5 score range. As regards this topic in order to receive high offspring yield BCS results indicating in goats pre-mating, mid pregnancy and final pregnancy should be theoretically closer to targeted scores. If no condition scoring is performed some problems occur in very thin goats (below 2 score), very fat goats (above 4 score) offspring yield problems are experienced which in turn bring about adverse economic results. Spahr (2004) and Villaquirán et al. (2012) recommend a BCS of 3.0 to 3.5 as optimal for goats in the breeding season.

Mellado et al. (1994), reported that kidding rates of goats having optimum BCS (3-3.5) are greater than those of goats having BCS 2 and BCS 5 . In does having high body condition, anoestrus season is shorter than does having low body condition (Forcada et al., 1992; Zarazaga et al., 2005). Furthermore, in females with lesser body condition, the frequency of short and long estrous cycles is greater than in does with greater body condition. Does in lesser body condition had more abnormal estrous cycles than those in greater body condition. In does in greater body condition, the ovulation rate is greater than in does with lesser body condition (Forcada et al., 1992; Scaramuzzi et al., 2006; Meza-Herrera et al., 2008). Hussain et al. (1996), have shown that low energy intake or BCS cause decreasing of fertility. Mellado et al. (1996), reported that kidding rates of goats having BCS 3 were around $20 \%$ lower than the rates of goats having BCS 4 or greater.

Body condition is a very important factor in determining potential milk production. It is also a useful tool to help monitor adequate feeding and management. There are two significant periods during which good body condition or change in the body condition is particularly important. Firstly, it is the monitoring body condition during late gestation and at kidding. Does need to be in good condition (BCS 3 to 3.5) at kidding to ensure that they have adequate body condition to help ensure the birth of viable kids, adequate colostrum production and reserves to help support high milk production, particularly in early lactation. This usually means that dry goats need to be sorted into at least two 
groups by body condition and fed accordingly to ensure that they all achieve as close to the ideal weight and body condition at kidding. Secondly, the does need to be fed adequately to minimize body weight loss in early lactation; an indication of good nutrition will also help increase milk production (Tarr and Gain, 2008; Zahraddeen et al., 2008). However, in most cases, there is a decrease in the body mass in early lactation when milk production is the high and an increase in body mass in later lactation with declining milk production. In such cases, body condition score is useful in adjusting supplementary feeding up or down (Girma and Alemu, 2012).

The existence of a negative relationship between milk yield and BCS in goats has been established $(r=0.24, \mathrm{P}<0.05)$ (Cabiddu et al., 1999). Graff (2011), has shown that a stronger negative correlation appeared as well as milk production only at the end of lactation. The decrease in the milk production resulted in the increase in the BCS $(r=-0.38)$. The poorer the BCS of the stock was the stronger the affect of the BCS on the milk production became. The animals are able to produce an adequate amount of milk if they are fed adequately and they are kept in a body condition in consistence with their lactation period. Does' BCS significantly influenced milk yield. This parameter increased with increase in the doe's BCS. MorandFehr et al., (1982) stated that within genetic limits, nutrition during lactation is the primary factor that influences milk yield. Milk yield was significantly influenced by parity. The parameter increased progressively with advance in parity. Butswat et al., (2002) reported that milk yield of goats increased significantly up to the third parity and declined subsequently.

The body condition is the outcome of on-farm husbandry and management and therefore, BCS can be a key tool in the on-farm assessment and management of welfare (Morgan-Davies et al., 2008; Phythian et al., 2011). At either end of the scoring scale a very thin or a very fat animal can indicate a potential compromise for the health and welfare of the individual goat and the flock. For example, emaciation may result from inadequate feed intake, molar tooth problems, and endo or ectoparasitism (Sargison and Scott, 2010). At the other extreme, obesity is a particular welfare concern for pregnant does, which may experience reduced appetites and could be at risk of developing pregnancy toxaemia (Jefferies, 1961).

\section{CONCLUSION}

The BCS of goat is a method to evaluate the nutritional status or the amount of body fat deposition for goats in some countries with developed goat husbandry in recent years. This method is according to a certain standard, using a series score to express the body condition of dairy goats. It is an important index to evaluate the productivity of herd, test and speculate the feeding level. The BCS in each physiological stage of does has significance to the evaluation of herd productivity. Control of the nutritional level of the goat to maintain a certain degree of body condition, keeps it not very fat or very thin, the reproductive performance of does could be ensured and the feeding cost also could be reduced to obtain great economic benefits. BCS is a simple but useful procedure, which can help producers make management decisions regarding the quality and quantity of feed needed to optimize performance. It can also play an important role in goat marketing.

\section{REFERENCES}

[1] Abdel-Mageed, I. (2009): Body Condition Scoring of Local Ossimi Ewes at Mating and its Impact on Fertility and Prolificacy. Egyp. J. Sheep Goat Sci., 4 (1): 37-44.

[2] Anonymus. (2010): Body Condition Scoring for Milk Goats. Ubisi Mail, March, 2010, 19-21. http://www. ubisimail.co.za/pdf_files/mar_10/PDF/milk_goats.pdf/ Accessed on 30 January 2012.

[3] Anonymus. (2012): Condition Scoring of Sheep. Technical Note TN640, ISSN 0142 7695, January 2012. http:// www.sac.ac.uk/mainrep/pdfs/tn640sheepcondscoringp.pd f/ Accessed on 30 January 2012.

[4] Arregu'In, J. A. A., Santos, R. E., Villa-Godoy, A., Román-Ponce, H. (1997): Dinámica Folicular Ovárica en Vacas Cebú con Diferente Condición Corporaly Frecuencia de Amamantamiento Durante el Per'Iodo Anovulatorio Posparto. División de Educación Continua, Unam, F. M. V. Z. (Eds.), VII Curso Internacional de Reproducción Bovina. Méx., D. F., pp. 210-240.

[5] Atti, N., Theriez, M., Abdennebi, L. (2001): Relationship Between Ewe Body Condition at Mating and Reproductive Performance in The Fat-Tailed Barbarine Breed. Anim. Res., 50: 135-144.

[6] Bicer, O (1991): Body Condition Scoring and The Important in Sheep Breeding. J. Agri. Fac., C.U., 6 (4): 81-88.

[7] Butswat, I. S. R., Zahraddeen, D., Mancha, Y. P., Dachollom, C. C. (2002): Effects of Breeds and Parity on Milk Yield of Red Sokoto and Sahel Goats. Proceedings of the 7th Annual Conference of Animal Science Association of Nigeria held at the University of Agriculture, Abeokuta, Nigeria, September 16-19, p. 17-21.

[8] Cabiddu, A., Branca, A., Decandia, M., Pes, A., Santucci, Pm., Masoero, F., Calamari, L. (1999): Relationship Between Body Condition Score, Metabolic Profile, Milk 
Yield and Milk Composition in Goats Browsing a Mediterranean Shrubland. Livest. Prod. Sci., 61 (2-3): $267-$ 273.

[9] Cisse, M., Baye. M. M., Sane, I., Correa, A., Diaye, I. N. (1992): Seasonal Changes in Body Condition of the Senegalese Sahel Goat: Relationship to Reproductive Performance. In: Proc. of the 2nd Biennial Conference of the African Small Ruminant Research Network AICC, Arusha, Tanzania, 7-11 December, 1992, p. 175-178.

[10] Colomer, F., Morand-Fehr, P., Kirton, A. H. (1987): Standard Methods and Procedures for Goat Carcass Evaluation, Jointing and Tissue Separation. Livest. Prod. Sci., 17: 149-159.

[11] Dinler, M. (2005): Alman Alaca X Kıl Melezi Sütçü Keçilerde Vücut Kondüsyon Puanı ile Canlı Ağırlık ve Döl Verimi Arasındaki Ilişkilerin Belirlenmesi Uzerine Bir Araştırma Cukurova Universitesi Fen Bilimleri Enstitüsü, Zootekni Anabilim Dal, Adana 2005. 44s.

[12] Forcada, F., Abecia, J. A., Sierra, I. (1992): Seasonal Changes in Oestrus Activity and Ovulation Rate in Rasa Aragonesa Ewes Maintained at Two Different Body Condition Levels. Small Rumin. Res., 8: 313-324.

[13] Girma, A., Alemu, Y. (2012): Sheep and Goat Production Handbook for Ethiopia. Sheep and Goat Management. Chapter Four. 34-57. http://issuu.com/esgpip/docs/ chapter_4_sheep_and_goat_management / Accessed on 30 January 2012.

[14] Gunn, R. G., Doney, J. M. (1975): The interaction of nutrition and body condition at mating on ovulation rate and early embryo mortality in Scottish Blackface ewes. $J$. Agric. Sci., 85:465-470.

[15] Hervieu, J., Morand-Fehr, P., Schmidely, P. H., Fedele, V., Delfa, R. (1991): Body Measurements Explaining Variations in Scores for The Sternal, Lumbar, and Caudal Regions Used to Estimate Body Condition in Dairy Goats. Options Méditerranéennes-Série Séminaires, 13: 43-56.

[16] Houghton, P. L., Lemenager, R. P., Hendrix, K. S., Moss, G. E., Stewart, T. S. (1990): Effects of Body Composition, Pre- and Postpartum Energy Intake and Stage of Production of Energy Utilization by Beef Cows. J. Anim. Sci., 68: 1447-1456.

[17] Hussain, O., Waldeland, H., Havrevoll, O., Eik, L. O., Andresan, O., England, I. V. (1996): Effect of Type of Roughage and Energy Level on Reproductive Performance and Energy Level on Reproductive Performance of Pregnant Goats. Small Rumin. Res., 21: 97-103.

[18] Jefferies, B. C. (1961): Body Condition Scoring and Its Use in Management. Tasm. J. Agric., 32: 19-21.

[19] Kinne, M. (2012): The Ins \& Outs of Body Condition. http://kinne.net/ins\&outs.htm / Accessed on 30 January 2012.

[20] Luginbuhl, J. M. (1998): Preparing Meat Goats for The Breeding Season. ANS 00-602MG. http://www.cals.ncsu. edu/an_sci/extension/animal/meatgoat/pdf_factsheets/AN S\%2000\%20602MG.pdf / Accessed on 30 January 2012.

[21] Luginbuhl, J. M., Poore, M. H. (2012): Nutrition of Meat Goats. http://www.cals.ncsu.edu/an_sci/extension/ animal /meatgoat/MGNutr.htm / Accessed on 30 January 2012.

[22] Mellado, M., Cantu, L., Suarez, J. E. (1996): Effect of Body Condition, Length of Breding Period, Buck: Doe Ratio and Month of Breeding on Kidding Rates in Goats
Under Extensive Conditions in Arid Zones of Mexico. Small Rumin. Res., 23: 29-35.

[23] Meza-Herrera, C. A., Hallford, D. M., Ortiz, J. A., Cuveas, R. A., Sanchez, J. M., Salinaz, H., Mellado, M., Gonzalez-Bulnes, A. (2008): Body Condition and Protein Supplementation Positively Affect Periovulatory Ovarian Activity by Non LH-Mediated Pathways in Goats. Anim. Reprod. Sci., 106: 412-420.

[24] Morgan-Davies, C., Waterhouse, A., Pollock, M. L., Milner, J. M. (2008): Body Condition Score as An Indicator of Ewe Survival Under Extensive Conditions. Anim. Welf., 17: 71-77.

[25] Oregui, L. M., Vicente, M., Garroj., S., Bravo, M. V. (1991): The Relationship Between Body Condition Score and Body Weight in Latxa Ewes. Zaragosa: CIHEAMIAMZ, p. 109-112.

[26] Ozder, M., Yurtman, Y., Koycu, E. (1995): Kondüsyon Puanı ve Koyun Yetistiriciliginde Kullanımı. Hayvansal Üretim Dergisi, 36: 1-10.

[27] Pennington, J. (2010): Body Condition Scoring of Sheep and Goats. University of Missouri, Lincoln University, U.S. Department of Agriculture and Local Extension Councils Cooperating. http://extension.missouri.edu/ jasper/documents/ag/news/11-10.pdf / Accessed on 30 January 2012.

[28] Phythian, C. J., Michalopoulou, E., Jones, P. H., Winter, A. C., Clarkson, M. J., Stubbings, L. A., Grove-White, D., Cripps, P. J., Duncan, J. S. (2011): Validating Indicators of Sheep Welfare Through a Consensus of Expert Opinion. Anim., 5: 943-952.

[29] Pugh, D. G. (2002): Diseases of The Gastrointestinal System. In: Sheep and Goat Medicine, Edited by Pugh D. G., Saunders W. B., p. 69-105.

[30] Radostits, O. M., Gay, C. C., Hinchcliff, K. W., Constable, P. D. (2007): General Systemic States and Pregnancy toxaemia in sheep. Veterinary Medicine. 10 edition. p. $1668-1671$.

[31] Rhind, S. M., Mc Millen, S., Mc Kelvey, W. A. C., Rodriguez Herrejon, F. F., Mcneilly, A. S. (1989): Effect of The Body Condition of Ewes on The Secretion of LH and FSH and The Pituitary Response to GonadotrophinReleasing Hormone. J. Endoc., 120 (3): 497-502.

[32] Rook, J. S. (2000): Pregnancy Toxemia of Ewes, Does and Beef Cows. Vet. Clin. North Am. Food Anim. Prac., 16: 293-317.

[33] Russel, A. (1984): Body Condition Scoring of Sheep. In Pract., 6: 91-93.

[34] Russel, A. J. F., Doney, J. M., Gunn, R. G. (1969): Subjective Assessment of Body Fat in Live Sheep. J. Agric. Sci., 72: 451-454.

[35] Sargison, N. D., Scott, P.R. (2010): The Implementation and Value of Diagnostic Procedures in Sheep Health Management. Small Rum. Res., 92: 2-9.

[36] Scaramuzzi, R. J., Murray, J. F., Downing, J. A., Campbell, B. K. (1999): The Effects Exogenous Growth Hormone on Follicular Steroid Secretion and Ovulation Rate in Sheep. Domest. Anim. Endocrinol., 17: 269-277.

[37] Sejian, A., Maurya, V. P., Naqvi, S. M. K., Kumar, D., Joshi, A. (2010): Effect of Induced Body Condition Score Differences on Physiological Response, Productive and Reproductive Performance of Malpura Ewes Kept in a 
Hot, Semi-Arid Environment. J. Anim. Phys. Nutr., 94: 154-161.

[38] Short, R. E., Bellows, R. A., Staigmiller, R. B., Berardinelli, J. G., Custer, E. E. (1990): Physiological Mechanisms Controlling Anestrus and Infertility in Postpartum Beef Cattle. J. Anim. Sci., 68: 799-816.

[39] Smith, M. C., Sherman, D. M. (1994): Nutrition and Metabolic Diseases. Goat Medicine Lea and Febiger, p. 527-562.

[40] Spahr, L. (2004): Body Condition Scoring in Meat Goats. http://bedford.extension.psu.edu/agriculture/goat/Body $\% 2$ 0Condition\%20Scoring.htm / Accessed on 30 January 2012.

[41] Sanson, D. W., West, T. R., Tatman, W. R., Riley, M. L., Judkins, M. B., Moss, G. (1993): Relationship of Body Composition of Mature Ewes with Condition Score and Body Weight. J. Anim. Sci., 71: 1112-1116.

[42] Tarr, B., Gain, S. 2008. Why are My Goats Milking Less than 8 Litres? http://www.nutrecocanada.com/docs/shurgain---goat/why-are-my-goats-milking-less-than- 8 litres. pdf / Accessed on 30 January 2012.

[43] Teixeira, A., Delfa, R., Colomer-Rocher, F. (1989): Relationships Between Fat Depots and Body Condition Score or Tail Fattness in The Rasa Aragonesa Breed. Anim. Prod., 49: 275-280.

[44] Villaquirán, M., Gipson, R., Merkel, R., Goetsch, A., Sahlu, T. (2012): Body Condition Scores in Goats. Langston University, Agriculture Research and Cooperative Extension. Langston, OK. http://www.ans.iastate.edu /faculty/morrical/acc/GoatResearch.pdf / Accessed on 30 January 2012.

[45] Yilmaz, M., Altin, T., Karaca, O., Cemal, I., Bardakcioglu, H.E., Yilmaz, O., Taskin, T. (2011): Effect of Body Condition Score at Mating on The Reproductive Performance of Kivircik Sheep Under an Extensive Production System. Trop. Anim. Health Prod., 43: 15551560 .

[46] Zahraddeen, D., Butswat, I. S. R., Mbap, S. T. (2008): Evaluation of Some Factors Influencing Growth Performance of Local Goats in Nigeria. AJFAND., 8 (4): 464 479.

[47] Zarazaga, L. A., Guzmán, J. L., Domínguez, C., Pérez, M. C., Prieto, R. (2005): Effect of Plane of Nutrition on Seasonality of Reproduction in Spanish Payoya Goats. Anim. Reprod. Sci., 87: 253-267. 